\title{
PENGARUH METODE LATIHAN LAY UP MENGGUNAKAN RINTANGAN DAN TIDAK MENGGUNAKAN RINTANGAN
}

\author{
Didi Muhtarom \\ STKIP Muhammadiyah Kuningan \\ email: didimuhtarom@gmail.com
}

\begin{tabular}{l} 
Info Artikel \\
\hline Sejarah Artikel: \\
Diterima Mei 2018 \\
Disetujui Juni 2018 \\
Dipublikasikan Juli 2018 \\
\hline Keywords: \\
lay up, metode, \\
latihan, bola basket \\
\hline
\end{tabular}

\section{Info Artikel}

Sejarah Artikel:

Diterima Mei 2018

Disetujui Juni 2018

\section{Abstrak}

Masalah yang menjadi latar belakang penelitian ini adalah 1). Dalam memberikan latihan lay up guru masih monoton dalam menggunakan metode latihan. 2). Siswa kurang antusias dalam menerima materi latihan lay up. 3). Pembelajaran menjadi membosan karena metode latihan yang diterapkan oleh guru monoton. Metode penelitian yang digunakan dalam penelitian ini adalah metode eksperimen Populasi dalam penelitian ini adalah siswa SMPN 1 Cigugur Kabupaten Kuningan yang tergabung dalam unit kegiatan ekstrakurikuler bola basket yang berjumlah 20 orang. Hasil dari penelitian ini yaitu : 1). Metode latihan lay up dengan menggunakan rintangan berpengaruh terhadap peningkatan hasil lay up dalam permainan bola basket siswa peserta ekstrakurikuler SMP Negeri 1 Salem secara signifikan. 2). Metode latihan lay up tanpa menggunakan rintangan berpengaruh terhadap peningkatan hasil lay up dalam permainan bola basket siswa peserta ekstrakurikuler SMP Negeri 1 Salem secara signifikan. 3). Metode latihan tanpa menggunakan rintangan lebih berpengaruh secara signifikan terhadap peningkatan hasil lay up dalam permainan bola basket siswa peserta ekstrakurikuler SMP Negeri 1 Salem secara signifikan.
Abstract
The problem that is the background of this research is 1). In providing lay-up exercises the teacher is still monotonous in using the training method. 2). Students are less enthusiastic in receiving lay up training material. 3). Learning becomes bored because the training method applied by the teacher is monotonous. The research method used in this study is the experimental method The population in this study were students of Cigugur 1 Public Middle School, Kuningan District, who joined the basketball extracurricular activities unit which numbered 20 people. The results of this study are: 1). Lay-up training method using obstacles has an effect on improving the lay-up results in basketball games of the extracurricular members of Salem State Middle School 1 significantly. 2). The method of lay-up training without using obstacles has an effect on improving the results of lay-ups in basketball games of the extracurricular participants of Salem State Middle School 1 significantly. 3). The method of training without using obstacles is more significantly influential in improving the results of lay-ups in basketball 
games of students of the extracurricular activities of Salem State Middle School 1 significantly.

(C) 2018 Didi Muhtarom

Under the license CC BY-SA 4.0

$凶$ Alamat korespondensi:

ISSN 2443-1117 (cetak)

E-mail : didimuhtarom@gmail.com

No Handphone : 081312657774 


\section{PENDAHULUAN}

Dalam suatu kompetisi atau pertandingan, penguasaan teknik olahraga sangat penting terutama dalam penguasaan teknik dasar olahraga bolabasket. Penguasaan teknik dasar yang baik harus benar-benar dikuasai oleh seorang pemain bola basket. Pada teknik yang baik mendapatkan gerakan efektif dan efisien perlu didasarkan pada penguasaan teknik dasar yang baik. Teknik dasar dalam olahraga bolabasket dapat dibagi sebagai berikut:1) Teknik melempar dan menangkap;2) Teknik menggiring bola;3) Teknik menembak;4) Teknik gerakan berporos;5) Teknik tembakan lay up;6) Merayah (Imam Sodikun, 1992: 48).

Dari beberapa teknik dasar bola basket yang telah dikemukakan di atas, bahwa Tembakan atau shooting merupakan teknik sangat penting untuk dikuasai dengan baik (Machfud Irsyada, 2000: 14). Tujuan olahraga bola basket adalah untuk menciptakan tembakan yang tepat dan mendapat angka pada setiap kesempatan, yang merupakan syarat regu tersebut dinyatakan pemenang. Menurut Machfud Irsyada (2000: 14) bahwa sesuai dengan tujuan utama olahraga bola basket itu sendiri yaitu memasukan bola sebanyak mungkin ke keranjang lawan dengan cara yang sportif sesuai dengan aturan yang telah disepakati. Regu yang dapat mencatat atau mencetak angka (score) paling tinggi adalah sebagai pemenang.

Penguasaan keterampilan teknik dasar merupakan salah satu tuntutan utama dalam melakukan permainan bola basket. Berkenaan dengan hal ini Harsono (1988:100), menjelaskan sebagai berikut : Kesempurnaan teknik-teknik dasar dari setiap gerakan adalah penting oleh karena akan menentukan gerak keseluruhan. Oleh karena itu, gerak-gerak dasar setiap bentuk teknik yang diperlukan dalam setiap cabang olahraga haruslah dilatih dan dikuasai sevara sempurna.

Terdapat beberapa macam bentuk teknik dasar dalam bermain bola basket, seperti yang dijelaskan oleh Haris (2000:18), menjelaskan bahwa :"Terdapat tujuh macam teknik dasar dalam bermain bola basket yaitu teknik melempar, menangkap, menggiring bola, menembak, gerak berporos (pivot), tembakan lay up, dan merayah (rebound)". Dari masingmasing teknik dasar tersebut memiliki fungsi peranan yang khas disesuaikan dengan sifat dari permainan bola basket yang cepat dan dinamis. Beberapa macam teknik dasar tersebut di atas, sesuai dengan karakteristik permainan dimana tujuan kemenangan dalam permainan dapat diindikasikan dengan jumlah bola yang dapat dimasukkan ke dalam jarring lawan. Salah satu usaha untuk memasukan bola ke dalam jarring lawan adalah melalui tembakan lay upteknik lay up ini merupakan teknik kombinasi dari menggiring bola yang dilanjutkan dengan memasukan bola kejaring.

Berkaitan dengan maslah kondisi fisik dalam olahraga, pada dasarnya kondisi fisik tersebut dapat ditingkatkan melalui latihan yang berkesinambungan dan terprogram. Terdapat beberapa macam metode latihan yang diterapkan. Salah satu metode dalam latihan adalah dengan latihan menggunakan rintangan dan tanpa rintangann. Berdasarkan pada pemaparan latar belakang masalah di atas, maka penulis merasa tertarik untuk mengamati peningkatan kondisi fisik dikaitkan dengan metode latihan yang dilaksanakan dalam meningkatkan keterampilan bermain. Adapun bentuk pengamatan tersebut, penulis tuangkan dalam penelitian yang berjudul "Pengaruh Metode Latihan Menggunakan Rintangan dan Tidak Menggunakan Rintangan Terhadap 
Penguasaan Keterampilan Lay-Up Dalam Permainan Bola Basket Siswa SMP Negeri 1 Salem".

\section{METODE PENELITIAN}

Metode penelitian yang digunakan dalam penelitian ini adalah metode eksperimen. Metode ini digunakan atas dasar pertimbangan bahwa sifat penelitian eksperimental yaitu mencobakan sesuatu untuk mengetahui pengaruh atau akibat dari suatu perlakuan atau treatment. Di samping itu penulis ingin mengetahui pengaruh variable bebas terhadap variable terikat yang diselidiki atau diamati. Dalam arti kata yang luas, bereksperimen ialah mengadakan kegiatan percobaan untuk melihat sesuatu hasil. Hasil itu akan menegaskan bagaimanakah kedudukan perhubung antara variabel-variabel yang diselidiki.

Gambar 1. design one group pretest-posttest

$\begin{array}{lll}\text { Pre Test } & \text { Treatmen } & \text { Post Test }\end{array}$

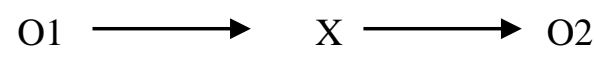

\section{HASIL DAN PEMBAHASAN}

Terlihat dari tabel diatas sebanyak 12 teste (40\%) telah mampu melakukan lay up sampai 8 kali masuk atau memperoleh skor 100 , sebanyak 10 teste $(33,3 \%)$ mampu melakukan lay uphingga 7 kali masuk atau memperoleh skor 88, sebanyak 4 teste $(13,3 \%)$ telah melakukan layup sampai 6 kali atau memperoleh skor 75 dan 4 teste $(13,3 \%)$ telah melakukan layup sampai 5 kali atau memperoleh skor 63. Berdasarkan data yang diperoleh menunjuk kanbahwa rata-rata kemampuan layup mencapai 7 kali masuk dari 8 kali testlay up. Dari 30 teste kemampuan terendah 5 kali masuk dan paling tinggi 8 kali masuk.

Terlihat dari tabel diatas sebanyak 10teste (15\%) telah mampu melakukan lay up sampai10 kali masuk atau memperoleh skor 100 , sebanyak 15 teste (50\%) mampu melakukan lay up hingga 9 kali masuk atau memperoleh skor 88, sebanyak 5 teste (17\%) telah melakukan layup sampai 8 kali atau memperoleh skor 75 dan 5 teste (17\%) telah melakukan lay up sampai 7 kali atau memperoleh skor 63 .

Terlihat dari tabel diatas sebanyak 4 teste (13\%) telah mampu melakukan lay up sampai 9 kali masuk atau memperoleh skor 100, sebanyak 10 teste (33\%) mampu melakukan layup hingga 8 kali masuk atau memperoleh skor 88, sebanyak 5 teste (17\%) telah melakukan lay up sampai 7 kali atau memperoleh skor 75 dan 11 teste (37\%) telah melakukan lay up sampai 6 kali atau memperoleh skor 63.

Berdasarkan hasil analsis regresi pada tabel diatas, diperoleh konstantase besar 10,329, dengan koefisien regresi untuk variabel kecepatan dribble menggunakan Rintangan sebesar 0,380 dan untuk variabel hasil Dribble Tanpa menggunakan Rintangan sebesar 0,414.

\section{SIMPULAN}

Berdasarkan hasil yang telah dipaparkan diatas dapat lihat bahwa dalam melakukan lay-up shoot yang memilki perubahan yang sangat signifikan adalah dengan melakukan latihan menggunakan 
haling rintang meiliki persentasi cukup tinggi sehingga bisa di tarik kesimpulan bahwa dalam melakukan lay-up shoot dengan menggunakan haling rintang dapat membantu seseorang dalam melakukan pola langkah yang baik.

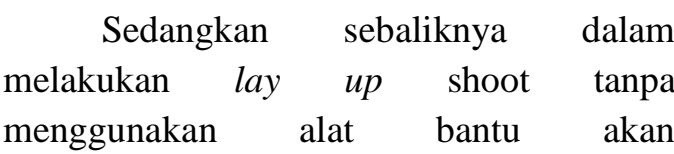
membutuhkan waktu yang sangat lama dalam meningkatkan kemampuan lay up shoot seseorang dikarenakan seseorang harus mebiasakan diri dengan polo langkahnya terlebih dahulu dan hambatan lainnya dalam kurang baiknya dalam melakukan pola langkah.

\section{DAFTAR PUSTAKA}

Achroni Keen.2012. Mengoptimalkan Tumbuh Kembang Anak Melalui Permainan Tradisional. Jogjakarta : java litera.

Arikunto Suharsimi. 2013. Prosedur penelitian. Jakarta: PT RINEKA CIPTA.

Bompa, T.O. 1993. Theory and Methology of Training, Kendal and Hunt Publishing: Company, Dubugue , Iowa

Mulyana. 2013. Pendidikan pencak silat. Bandung: PT REMAJA ROSDAKARYA.
Rahmayani, Mikanda. 2014. Buku super lengkap olahraga. Jakarta timur: duniacerdas.

Sugiyono. 2015. Metode penelitian pendidikan. Bandung: alfabeta.

Iskandar, D. (2017). Pengaruh Pelatihan Kesegaran Jasmani Terhadap Prestasi Olahraga. JUARA : Jurnal Olahraga, 2(1), 11-17. doi:10.33222/juara.v2i1.28

Julianto, I. (2016). Upaya Meningkatkan Kebugaran Jasmani Melalui Sirkuit Training Kids pada Siswa. JUARA : Jurnal Olahraga, 1(1), 7-14. doi:10.33222/juara.v1i1.56

Ramadan, G \&Iskandar, D. (2018). Pengaruh gaya mengajar dan motivasi belajar terhadap hasil belajar lay-up shoot. Jurnal Pendidikan Edutama 5 (1), 17-22. doi: 10.30734/jpe.v5i1.133

Sajoto. 2005. Teknik Permainan Bola Besar. Semarang : FIK UNNES.

Praja, H. (2017). Implementasi Model Pembelajaran Terhadap Keterampilan Sosial Dan Keterampilan Dasar Permainan Bola Basket. JUARA : Jurnal Olahraga, 2(2), 128-142. doi:10.33222/juara.v2i2.52

Widiarni. 2009. Peranan Latihan dalam Olahraga. Surabaya : Kartika

Moh. Nazir. 2014. Metode Penelitian. Bogor : Ghalia Indonesia 